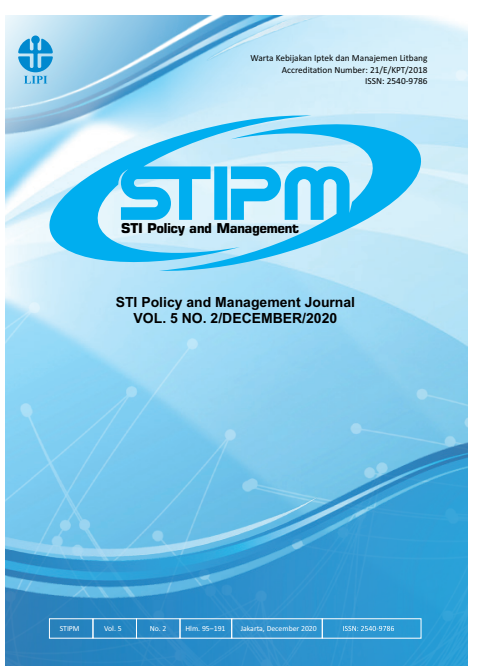

Journal of STI Policy and Management

Publication details, including instructions for authors and subscription information: http://www.stipmjournal.org/

\title{
Changing Stages of System Innovation at The Ombi- lin's Coal Mines of Sawahlunto: From Ghost Town to World Heritage \\ Erwiza Erman
}

Research professor in social history, Research Center for Area Studies, the Indonesian Institute of Sciences (LIPI)

Version of record first published: 15 December 2020

To cite this article: Erman, E. (2020). Changing Stages of System Innovation at the Ombilin's Coal Mines of Sawahlunto: From Ghost Town to World Heritage. Journal of STI Policy and Management, 5(2), 105-119.

To link to this article: http://dx.doi.org/10.14203/STIPM.2020.284

ISSN 2540-9786 (Print); ISSN 2502-5996 (online)

Accreditation Number: 21/E/KPT/2018

Full terms and conditions of use: https://creativecommons.org/licenses/by-nc-sa/4.0/

You are free to:

- Share : copy and redistribute the material in any medium or format

- Adapt : remix, transform, and build upon the material

- The licensor cannot revoke these freedoms as long as you follow the license terms.

Under the following terms:

Attribution - You must give appropriate credit, provide a link to the license, and indicate if changes were made. You may do so in any reasonable manner, but not in any way that suggests the licensor endorses you or your use.

NonCommercial - You may not use the material for commercial purposes.

ShareAlike - If you remix, transform, or build upon the material, you must distribute your contributions under the same license as the original.

No additional restrictions - You may not apply legal terms or technological measures that legally restrict others from doing anything the license permits.

Notices:

- You do not have to comply with the license for elements of the material in the public domain or where your use is permitted by an applicable exception or limitation.

- No warranties are given. The license may not give you all of the permissions necessary for your intended use. For example, other rights such as publicity, privacy, or moral rights may limit how you use the material.

- If you copy the dataset merely to extract the uncopyrightable data elements would not need permission to do so. However, if you republish the full dataset or using the copyrightable data layers require permission from the Research Center for STIPM, Indonesian Institute of Sciences. 


\title{
JOURNAL OF SCIENCE, TECHNOLOGY AND INNOVATION POLICY AND MANAGEMENT (STIPM JOURNAL), Volume 05, Issue 02, December 2020
}

\author{
FOREWORD by EDITOR-in-CHIEF
}

We are pleased to present to the readers with the fifth issue of the Journal of Science, Technology and Innovation Policy and Management. In this issue, we continue to publish the results of interdisciplinary scientific researches in various aspects of STI Policy and Management. This issue, prior issues, and other resources are available at www.stipmjournal.org.

We thank the reviewers and editorial boards for taking their precious time to ensure the quality of the articles through the double-blind peer review process. The seven articles in this volume cover a wide range of topics in STI policy and R\&D governance and management. In this issue, we introduce a special topic on Original Concept Formation. This is a new focus and scope of STI Policy and Management Journal. A concept formation in technology policy (TP) and management of technology (MOT), including proven soft technology concept based on rigorous data, cumulatively published references, and long experiences in the academic sphere. The original concept formation should deal with soft technology problems, policy context for problem-solving, concept formation, and its effective implementation.

M. Nawaz Sharif presents an original concept formation entitled Technology for Development: Ten True Stories Revealing the Complexity of Replicating South Korean Success. The essay comprises ten true stories presented to highlight personally observed problems encountered by Asian developing country leadership who tried to replicate South Korean success in fostering technology innovation induced sustainable economic growth strategy without paying robust attention to the crucial role of creating an "innovation climate/culture" as a necessary foundation for myriad development efforts.

The subsequent articles revealed research findings on the various issue of STI policy and R\&D governance and management. First article is presented by Erwiza Erman entitled Changing Stages of System Innovation at the Ombilin's Coal Mines of Sawahlunto: From Ghost Town to World Heritage. This paper examines system innovation, a transition from one socio-technical system to another by transforming the historical and cultural area into a world heritage city. The objective of this study is to reconstruct the changing stages of system innovation in achieving the World Heritage status at the Ombilin coal mines site of Sawahlunto.

The second article is composed by Rachmini Saparita and Savitri Dyah, entitled Mechanism of Implementing Technology in the Community of Eastern Indonesia (Case Study in Belu Regency, Nusa Tenggara Timur Province). This paper focuses on the mechanism of technology implementation to increase society's welfare. The study also evaluated technology implementation activities in the period 2003 to 2019, using meta-synthesis. The analysis found that there are five types of technology transfer mechanisms carried out by researchers at LIPI. 
The third article is composed by Budi Triyono, Ria Hardiyati, and Aditya Wisnu Pradana, entitled Lack of Contribution of the Indonesian R\&D Program to Economic Sector: Learning from the RPJMN Implementation. Through a review of the National Medium-Term Development Plan (RPJMN) documents on the S\&T Sector period of 2015-2019, this article attempts to analyze various obstacles related to the minimal contribution of Indonesian R\&D Programs in supporting Indonesia's economic sector and national competitiveness.

Wati Hermawati presents an article entitled Key Success Factors in Managing and Implementing Public Funded R\&D Projects in Indonesia. In this paper, she mentioned that the role of public-funded $\mathrm{R} \& \mathrm{D}$ institutions in supporting innovation and economic performance of MSMEs (micro, small and medium enterprises) is still very small. Therefore, the success factors in managing and implementing $R \& D$ projects at $R \& D$ institutions should be identified, particularly in providing solution for MSMEs' problems. Through the two case studies, this article provides key success factors and lessons learned to improve R\&D project activities at PRCs.

The fifth article is presented by Trina Fizzanty, Kusnandar, Sigit Setiawan, Radot Manalu, and Dini Oktaviyanti, entitled The International Research Collaboration, Learning and Promoting Innovation Capability in Indonesia Medical Sectors. This article presents the case of eight international collaborative research projects in medical research in Indonesia. The research found that International research collaboration has opened the opportunity for Indonesian researchers to learn and upgrade their capability and contribute to the scientific arena. However, none of international research projects reached the commercialization stage yet, but some of which were at the beginning of clinical trial stage.

Finally, Budi Harsanto presents an article entitled Eco-innovation Research in Indonesia: A Systematic Review and Future Directions. The article analyzes the recent development of eco-innovation research in Indonesia and provides some potential avenues for future research. The analysis was carried out using Systematic Literature Review (SLR) techniques to synthesize knowledge development of a scientific field in a structured, transparent, and reliable manner.

The editor of STIPM Journal are dedicated to working with scholars in existing and emerging STI issues and produce high-quality papers to expand knowledge in the field of STI Policy and R\&D Governance and Management. We believe that all the papers published in this issue will greatly influence on the STI Policy and Management for Sustainable Development.

The STIPM Journal is indexed by Google Scholar, ISJD, IPI, DOAJ, BASE, SINTA, and OCLC World Cat. This makes the journal dissemination wider.

The editor-in-chief acknowledge and are very grateful to the authors, the editorial board, the section editors, the designer, the staff of the LIPI Press Publishing Office, and everyone who has contributed to the publication of the STIPM journal. We are also very grateful to our future readers. By inviting the readers to publish your research results articles in this journal, we believe in the meaningfulness and future collaboration as well as to provide a higher scientific platform for the authors and the readers, with a comprehensive overview of the most recent STI Policy and Management research and development at the national, regional, and international level.

Happy New Year 2021 to all of you!

Jakarta, 15 December 2020

Editor-In-Chief 



\section{JOURNAL OF STI POLICY AND MANAGEMENT}

Volume 5, Number 2, December 2020

\section{LIST OF CONTENTS}

Technology for Development: Ten True Stories Revealing the Complexity of Replicating South Korean Success

M. Nawaz Sharif.

Changing Stages of System Innovation at the Ombilin's Coal Mines of Sawahlunto: From Ghost Town to World Heritage

Erwiza Erman

Mechanism of Implementing Technology in the Community of Eastern Indonesia (Case Study in Belu Regency- Nusa Tenggara Timur Province)

Rachmini Saparita and Savitri Dyah

The Gap between Program Planning and Implementation: The Case of R\&D Program in Indonesian RPJMN

Budi Triyono, Ria Hardiyati, and Aditya Wisnu Pradana

Key Success Factors in Managing and Implementing Public Funded R\&D Projects in Indonesia

Wati Hermawati

The International Research Collaboration, Learning and Promoting Innovation Capability in Indonesia Medical Sectors

Trina Fizzanty, Kusnandar, Sigit Setiawan, Radot Manalu, and Dini Oktaviyanti

Eco-Innovation Research in Indonesia: A Systematic Review and Future Directions 



\title{
if STI POLICY AND MANAGEMENT \\ LIPI Journal homepage: http://www.stipmjournal.org
}

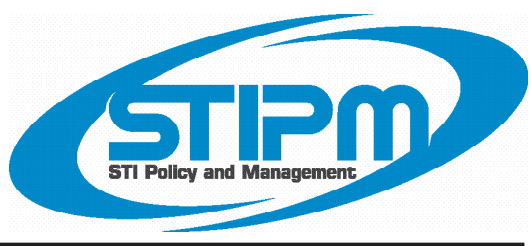

\section{Changing Stages of System Innovation at the Ombilin's Coal Mines of Sawahlunto: From Ghost Town to World Heritage}

\author{
Erwiza Erman \\ Research professor in social history, Research Center for Area Studies, \\ the Indonesian Institute of Sciences (LIPI)
}

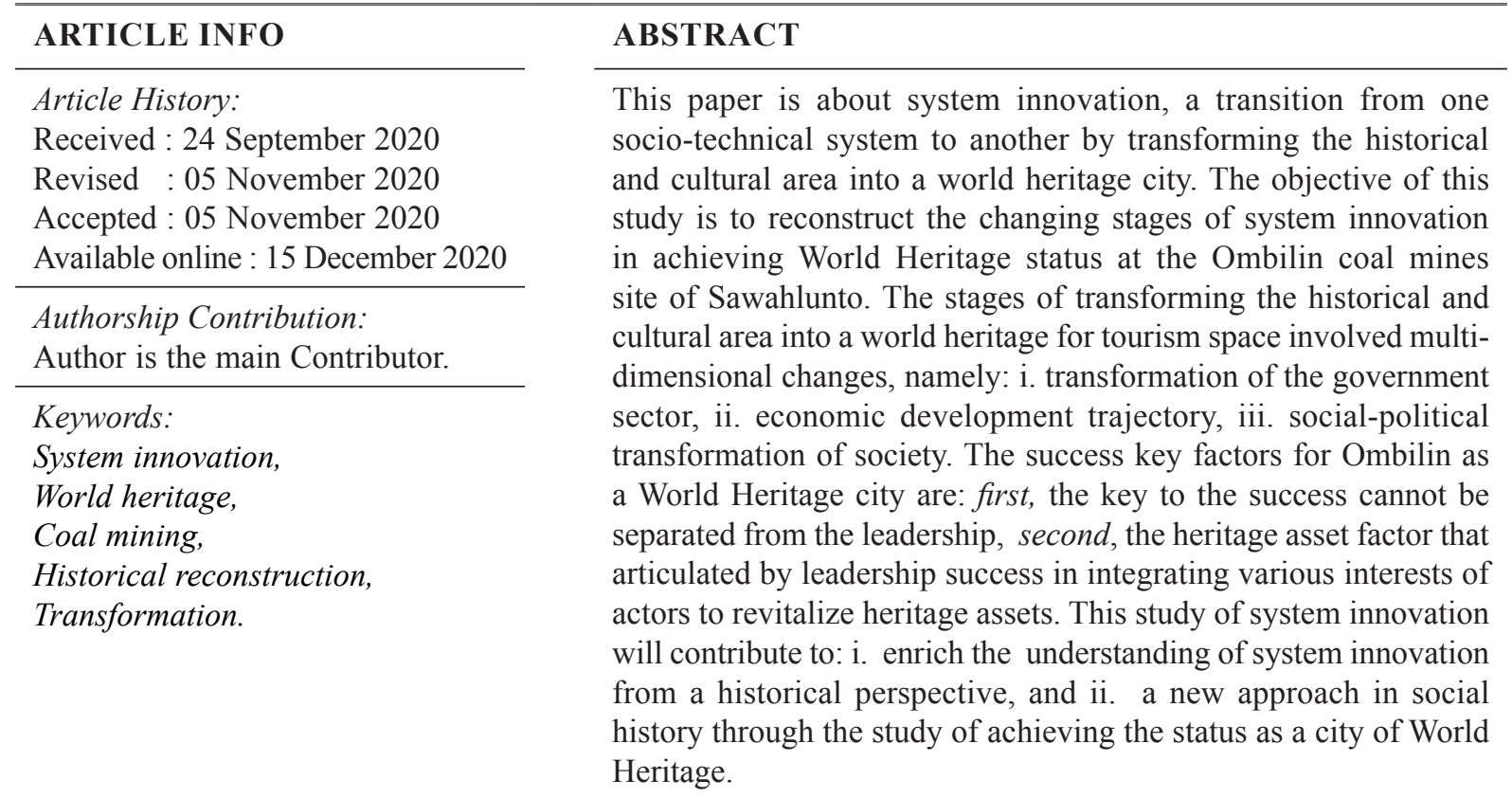

C2020 P2KMI-LIPI All rights reserved

\section{INTRODUCTION}

\subsection{Background and Objective}

The Ombilin coal mines of Sawahlunto was recognized by UNESCO as one of the World Heritage Site (WHS) in 2019. The achievement of Ombilin listed in World Heritage was based on meeting the criteria of the outstanding universal value (OUV). In defining cultural heritage, the World Heritage Convention notes that "monuments" and

\footnotetext{
* Corresponding Author.

E-mail: erwiza_e@yahoo.com
}

"groups of buildings" should have OUV from the point of view of history, art, or science, while the "sites" are also seen from the ethnological or anthropological points of view (Jokilehto, 2006).

Before recognized as a World Heritage Site, The Ombilin coal mines was called as ghost town, where coal mining company leaves behind a large number of tangible or intangible remains. A part of them can be used by different actors as a mining heritage. Specific cultural or social values and meanings, which remind of the importance of mining in the past and today, are represented through this mining heritage. To preserve them, 
the heritage must be passed to future generations. One of the ways is mining tourism. However, the relation between the mining heritage and tourism is not as simple as the complex mining heritage has many specific features that differ from the traditional tourist attractions and conceal many pitfalls (Jelen, 2018).

The Transformation from ghost town to World heritage was a long way that involved the network of the Ombilin administration, coal mine company, academic community, local people, and other stakeholders. It was a challenging activity because transforming the historical and cultural area into a world heritage for tourism space involved changes in the actors' network, interest relations, and adjustments of the power relations among actors. Business enterprises became new actors and residents gradually gained more decision-making rights, with the supervision of UNESCO World Heritage Committee (Wang and Xiao, 2020).

Transforming the historical and cultural area into a world heritage for tourism space is a system innovation, which is defined as a transition from one socio-technical system to another. Much more profound examples of system innovation are agricultural revolution and industrial revolution, both of which fundamentally changed how the society operates. The society is currently experiencing another profound system innovation determined by the rapid development and diffusion of information and communication technologies (ICT). The system innovation is a transformation which takes place at the wider societal context. It covers not only product and process of technical innovations, but also changes in market and management, policy, regulatory, institution, infrastructure, economy, social, culture, and values embedded in system innovation (Brujin et al., 2004).

The transition process from ghost town to World Heritage of Sawahlunto is important to increase the welfare of common people by attracting tourists. With the status of WHS, the number of tourists increased to enjoy the historical and cultural heritage of the mine and its narratives. The importance of transition has been realized by people of the town since the period of Amran
Nur as the major of Sawahlunto for two periods (2003-2013) until up to the present. Some people could rent their houses for the tourists, and some others started to be involved in informal economic sector. In order to make these governmental programs successful in the tourist industry, the major was assisted by consultants from various disciplines. He took initiatives to revitalize some historical and cultural buildings and the tragic and dramatic history of chained miners. He also started collaboration with many parties, local and central government, academicians, and informal leaders.

The objective of this study is to reconstruct the changing stages of system innovation in achieving the World Heritage status at the Ombilin coal mines site of Sawahlunto. This process cannot be separated from many interrelated elements of state policy, economic development of coal, and decreasing economic conditions of the town society of Sawahlunto. On the basis of these conditions, the specific questions of the study are: i. how the stages of transforming the historical and cultural area into a world heritage for tourism space had been pursued by the Ombilin coal mines of Sawahlunto; ii. what the benefit of transformation for local people, and iii. what success key factors and future challenges for Ombilin as World Heritage city.

The knowledge gained from this historical reconstruction will contribute to not only the social history of achieving the status of a World Heritage city but also to enrich the understanding on system innovation from a historical perspective. The practical contribution of the results are to get new insights of historical and cultural knowledge and educate the visitors about the story of combination of local and global technology in the coal mines.

The next subsection is the methodology of reaching the objective of the study, followed by a literature review on the management of World Heritage city for sustainable tourism. The analytical framework of system innovation will be presented afterward. The section of reconstruction results focuses on the changing stages of system innovation, and the discussion section will explain how interrelated multi-dimensional 
changes occurred, then the outcome of transformation, success key, and future challenges for the future will be highlighted. Finally, the conclusion of the study will be presented.

\subsection{Methodology}

Methodology of this study follows the systemic action research (Burns, 2007). It is the processes of in-depth inquiry, multi-stakeholder analysis, experimental action, and experiential learning, enacted across a wide landscape of research. There are processes by which communities and organisations can adapt and respond purposefully to their constantly changing environments. The processes are as follows:

a) Define the context bound and addresses the content of problems, that is a wider social context of pursuing the path towards Word Heritage;

b) Proceed inquiry where participants and researchers contribute to knowledge through collaborative communication processes, in which all participants' contributions are taken seriously. The in-depth inquiry is done by having conversations for better information sharing among multi stakeholders based on experimental action and experiential learning, while the process inquiry is done by reading historical data such as Staatsblad. This information was cross-checked by doing in-depth interviews with various informants, such as state actors, informal leaders, common people, and former workers of the Ombilin coal mines. Apart from the methods mentioned above, this research also used direct observation periodically, since I was doing fieldwork for my dissertation in 1995 up to 2019.

c) Treat the diversity of experience and capacities within the local group as an opportunity for the enrichment of the research-action process. The mutual adjustment among multi-stakeholders' position was achieved by having a consensus on the path of trajectory towards Word Heritage;

d) Evaluate the meanings in the inquiry process lead to social action or these reflections on action lead to the construction of new meanings, especially before and after Sawahlunto recognized by UNESCO.

e) Implement the credibility of action research knowledge, which is measured according to whether actions that arise from it solve problems (workability) and increase participants' control over their own situation. This has been done since the early years of the implementation of Vision and Mission of the town in 2002.

\section{LITERATURE REVIEW}

\subsection{Management of World Heritage City}

The attractiveness of mining site as historical and cultural heritage sources is related to maintain a balance between preserving mining heritage, containment of environmental risks, tourism, and rural development (Ateş, 2016). It depends on the role of main stakeholders in historical and cultural tourism promotion. There are three types of stakeholders involved in historical and cultural tourism promotion: first, government agency, which is responsible for the management of tourism and the city's historical sites of World Heritage under the supervision of UNESCO; second, entrepreneur, which is the support element of enhancing cultural tourism by promoting the best quality of services in hospitality, restaurant, tourism business, lodging business, and tourism training business and third, the general public that understood and agreed with government management that they have the duty to participate in the preservation of national cultural heritage under the "Live World Heritage Town" concepts and management of UNESCO (Khlaikaew, 2015).

The management of world heritage cities should be implemented under UNESCO's directives. The actual managerial system of a World Heritage Site (WHS), which is operated by the city administration, will be evaluated by UNESCO. The knowledge related to the management of world heritage cities is important. The world heritage city management system can be improved by including relevant stakeholders to reach better results (Petric, Hell, \& Der Borg, 2020). 
The historical heritage of cities should be managed for the purpose of the region's social and economic development. By managing internal tourism, objects of historical and cultural heritage become an important asset of the cities, making profit and significantly influence social and economic development. The social and economic roles of historical and cultural heritage are providing additional job openings, reviving local cultural values, and developing local creativity, and traditions (Ismagilova, Safiullin, \& Gafurov, 2014).

The social value of heritage is important in relation to sustainable tourism. There are multiple factors determining the social value of heritage, namely: existential, aesthetic, economic, and legacy values and the risks associated with the underestimation of contemporary social values (Dans \& González, 2020). Aesthetic values provide an ideal association with the sense of tradition and are manifested through an appreciation of cultural and historic heritage. Marrying heritage and the aesthetic, forming a strong association where one supports the other, was the single most important key factor for the success in protecting the historical and cultural heritage sites (Milne, 2011).

\subsection{Sustainable tourism system for World Heritage City}

Tourism firms take advantage of inter-organizational relationships by forming clustered tourism firms in World Heritage City. The inter-firms network with a great diversity of relationships to obtain knowledge exploration, which is critical for developing radical innovation. A higher capacity to develop radical innovation will give a tourism destination a competitive advantage and a better image compared to other tourism destinations with similar characteristics, hence becoming more competitive in terms of attracting tourists. Moreover, tourism institutions should foster a variety of interorganizational relationships as part of a strategic development plan, as this would create a sustainable tourism system for World Heritage Cities (Martinez-Perez, Elche, \& Garcia-Villaverde, 2018).
Entrepreneurial Ecosystems (EEs) in tourism address gaps in our understanding of the environments within which physical and virtual elements of EEs interact, change, and expand over time. EEs are removing some of the traditional 'boundaries'. For example, a Go-car driver may transport locals to work as part of the host infrastructure, offer services directly to tourists, or engage another service provider - such as a guide. For the local resident, their perspective of the EEs could be either as a host or as a guest, depending on, for example, if they are a traveloka market place or local taxi provider; or if they are themselves guests of local community-based attraction i.e., 'domestic tourist'(Milwood \& Maxwell, 2020). Innovation is a useful tool in rural tourism, especially in providing guesthouse. Guesthouse owners always need to innovate by improving the products and services that they offered. The reasons for increasing the innovation were not only a growth of profit in the short term, but also the growth of customer number and their loyalty in the medium and long term (Cosma et al., 2014).

There is an affirmative relation between the presence of heritage sites and amount of tourism. The local population plays a key role and benefits from cultural tourism through the deployment of the cultural capital and embodied it (Farid, 2015). The failure to utilize the competitiveness for the economic benefits of their local community has proven that a high record of tourists number does not mean that the local community would actually benefit from the tourism development (Amir et al., 2015 The local residents' participation is an essential aspect of effective tourism governance. The innovation-centered approaches and destination leadership provide opportunities to revitalize local resident participation in tourist destinations (Bichler, 2019).

COVID-19 has major impacts on three major tourism stakeholders, namely tourism demand, supply and destination management organizations, and policymakers. Despite decrease in the tourism market, COVID-19 has boosted such tourism social ventures aiming to create social value, solve social problems created by the COVID-19, and provide help to people in need, e.g., marketplaces enabling the repurposing 
of various unutilized tourism resources such as labor, hotel and function space, food, and cleaning material (Sigala, 2020).

\section{ANALYTICAL FRAMEWORK}

The lens of the study used the concept of dynamic multi-level perspective on system innovations (Geels, 2004). The concept has four characteristics: First, the multi-level perspective by using interdisciplinary approach that helps to understand the complexity of the real-world process of developments. The interdisciplinary approach will explain the whole story and through the multi-level perspective, it becomes clear that system innovations cannot be pushed by a single actor or be triggered by a single event. Such a transition is the result of linkages between developments at multiple levels. Second, the transformation from an old system to a new system configuration is triggered by the emergent phenomena embedded in the old system, because societal changes are built based on the accumulation of earlier developments. Third, the transition involved two phenomena, the emergent phenomena embedded in old system, and the emergent phenomena incorporated in the new system configuration. The relationship between the two phenomena can be mutual, enforcing or competing with each other. Fourth, the single actors or social groups cannot bring transitions. It is the interplay and alignment between interactive component inside the system, such social groups interaction leads to transitions.

The Multi-Level Perspective (MLP) is a prominent framework to understand socio-technical transitions as evolutionary, interpretive, and conflictual processes (Geels, 2019a). Making sustainability transitions concerns on core processes, stages and change mechanisms, key cross-cutting themes, and governance-related challenges for steering transition processes (Turnheim, Asquith, \& Geels, 2020). Such process of socio-technical transitions involves multidimensional struggles between radical niche innovations and incumbent systems (Geels, 2019b). The underlying mechanisms of these change processes are identified by using the multi-level perspective. There are three types of identified change processes: reproduction, transformation, and transition. 'Reproduction' refers to incremental change along existing trajectories. 'Transformation' refers to a change in the direction of trajectories, related to a change in rules that guide innovative action. 'Transition' refers to a discontinuous shift to a new trajectory and system (Geels \& Kemp, 2007).

Transitions come about through dynamic processes within and between three analytical levels: i) niches, which are protected spaces and the locus for radical innovations; ii) socio-technical regimes, which represent the institutional structuring of existing systems leading to path dependence and incremental change; and ii) exogenous socio-technical landscape developments (Kohler et.al., 2019) More specifically, there are four types of transition pathways, namely transformation, reconfiguration, technological substitution, and dealignment and realignment. These pathways differ in combinations of timing and nature of multi-level interactions (Geels \& Schot, 2007).

On the basis of the perspective above, the author formulates the analytical framework of changes in the Ombilin-Sawahlunto region as stages of system innovation. Shifting, transforming, and developing the OmbilinSawahlunto region are: i. from village into mining town; ii. from mining town to civilized town with mining tourism, and iii) from the civilized town with mining tourism into a World Heritage city. The system innovation is a long way of changes in interactive components inside the system and shifts to another system. In shifting from village to mining town, the interactive components of the system consist of village or nagari administrative to capital of sub-district VII Kota, district of Tanah Datar, and to the modern town. In the transition from a mining town to a civilized town with mining tourism, the interactive components of system comprise local, national bureaucrats, academicians, 
politicians, and local society. In developing a civilized town with mining tourism towards Word Heritage City, the interactive components are configurated more widely and varied by local, regional, national, and international actors, such as bureaucrats, academicians, and society, such as travel agencies.

The new system configuration is sustainable tourism in Word Heritage City, which is balancing economic, ecological, and social dimensions. The new system respects the principles of nature, by maintaining the preservation of tourism sites. For local people welfare, they gained benefit from sustainable tourism business. The transition into a new system required a process of interrelated stakeholders of various disciplines, namely historian, architect, anthropologist, archaeologist, mining engineers, city planner, environmentalist, etc. The transition cannot be understood without taking note of earlier developments of "little Dutch heritage" in the Ombilin-Sawahlunto region. The process of transition is the dynamic of seeking consensus between competing stakeholders, i.e., major of the town, mining company (PTBA-UPO), and local society. Such dynamic interactive process is the success key in developing the Ombilin-Sawahlunto from a civilized town with mining tourism into a World Heritage city (See figure 1).

\section{CHANGING STAGES OF SYSTEM INNOVATION}

\subsection{Transformation from a village to a modern mining town (1892-1999)}

In the past, Sawahlunto was a small village in a valley, with narrow flatland for rice fields, surrounded by hills, like a frying pan. This village was surrounded by forests and was seen as an unprofitable area by the Dutch colonial officials. According to a rough estimation by the Dutch, Lunto village only had a population of 500 people in the mid-19th century. However, this area was suddenly promising when a young Dutch engineer, W.H. de Greeve discovered coal deposits of 200 million tonnes at this site in 1867 (Greeve, 1871). The discovery of this coal deposit has caused prolonged discussion in the Dutch Parliament regarding its management system, whether it would be exploited by the state or by the private sector (Colombijn, 1992). After 20 years of discussion, in 1891, the colonial

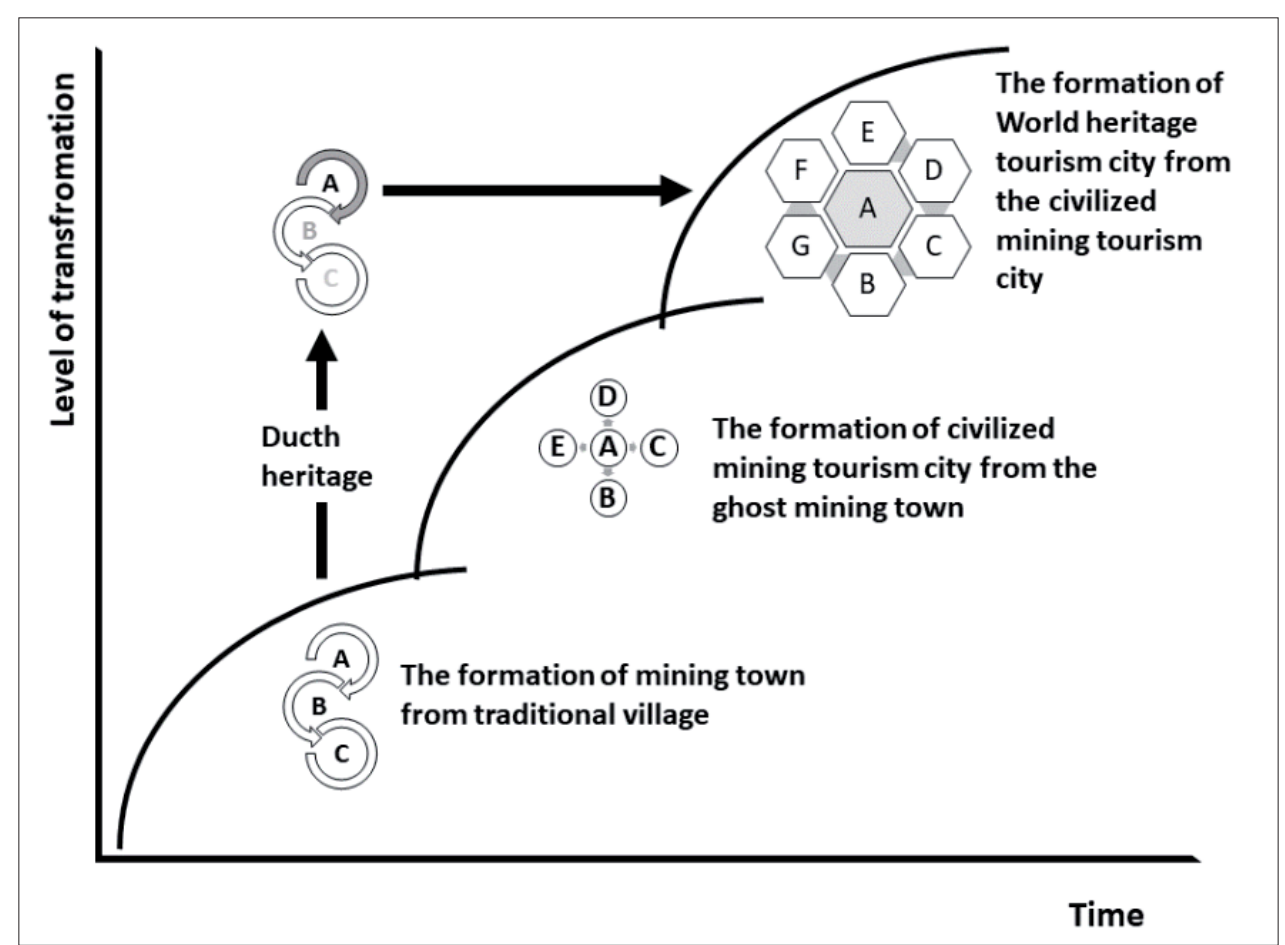

Figure 1. Changing stages of system innovation: from ghost town to word heritage. 
government finally decided to manage it with an initial capital of 5.5 million guilders (Asoka et al., 2005). A state-owned company was known as Het Ombilin Steenkolen Mijnen. After independence, the colonial state company was taken over by the Indonesian government and turned into a state-owned Company (PN), and became part of PTBA (Bukit Asam) later on.

As a city with an economy driven by coal mining, the growth of its population goes hand in hand with the development of this commodity. In 1930, the population had reached 43,576 people, during periods of high coal productivity reaching 624,212 tonnes in 1930. In the gloomy years of coal economy, it was even planned to close. In 1936, 1951, and 1969, large numbers of the workforce left the city (Erman, 2005). Therefore, it is not surprising that population growth is so low, because in the 4 years (1995) before the company closed its business (1999), the population of the city was only 55,090 people, and it decreased to 50,668 in 2000 (BPS Kota Sawahlunto, 2010). Many workers have moved to work in coal mining in Kalimantan or return to their hometowns.

The transformation process from a village to a mining town as a system innovation is related to the interaction of two system components, namely coal exploitation and political, social, economic, and cultural fields. First, the exploitation of coal as a subsystem is the interaction of elements of capital, land, labor, and various supporting facilities for production, coal marketing, coal consumers, and the mining community, such as office facilities for companies, housing for various social classes in the mining communities, education, places of worship, sports, hospitals, food distribution, markets, drinking water, and entertainment venues for high social classes. In addition, the government also built office facilities for the government to control mining communities. Strict control especially over chained people (orang rantai) recruited by the Ministry of Justice (Het Departemen van Justitie) to become forced labour at the Sawahlunto coal mines. (Dwangarbeiders, 1925). Roads, bridges, trains, ports connecting mining sites, and collection points were constructed to bring coal from Sawahlunto to Emma Haven Port (Teluk
Bayur) for consumers, especially in Java. In West Sumatra, the lime factory in Padang Panjang and the cement factory in Padang were the two biggest consumers of coal apart from being used for railways.

Second, coal exploitation equipped with modern facilities mentioned above is a response to the transformation process in political, social, economic, and cultural fields. The position of Sawahlunto became important, in this place the offices of the Controller of Kota VII and Assistant Resident of Tanah Datar were originally assigned to oversee the chained mine workers outside mines. In 1918, Sawahlunto officially became a city driven by the presence of mining companies and mining communities. In addition, immigrants from various regions inside and outside West Sumatra benefited from the multiplier effects of the presence of mining companies. Mining city communities and mining communities are heterogeneous in terms of race, ethnicity, religion, and culture. Generally, the people of Sawahlunto city consist of European, Indo-European, Chinese, natives from various ethnic groups, namely Minangkabau, Nias, Batak, Javanese, Sundanese, Madurese, and Bugis. This heterogeneity in ethnicity, religion, and culture still continues today, even though Europeans and Indo Europeans have returned to the Netherlands, before the Japanese occupation (1942-1945). This ethnic, religious, and cultural heterogeneity has become one of the social capitals for the city government to develop its vision and mission as a cultured mining tourism city since 1999 .

\subsection{Transformation from a ghost town to the city of civilized mining tourism (1999-2019)}

The 1997 economic crisis and the political shift from the New Order regime to the Reform Era in 1998 brought a transformation in the Indonesian mining economy. Many mining companies have faced protests from local government and local community. Protests about company management, where representatives of local people demanded that shares had to be given to the regions to manage mining companies. (Erman, 2007). At the same time, local people 
and immigrants invaded mining company areas to mine illegally. The condition of the mining town of Sawahlunto has become even tougher. Cities that depend on the development of coal exploitation have become dead cities or "ghost towns". PT Bukit Asam (PTBA) which manages the Mining Unit in Ombilin was forced to stop its production. The transformation process from a ghost town to a mining tourism city, as an innovation system is concerned with the interaction of five components: i. stagnation of coal production, ii. decreasing government revenue sources, iii. sectoral innovation (tourism) as a source of government revenue, iv. local community participation, and v. historical and cultural-based innovation.

First, coal production has decreased dramatically due to depleting coal deposits and it is not economically mined, also as a result of coal camps burning attacks done by the local people and their claims to mining exploitation lands, which are managed by the company. The company was busy taking care of social problems that hinder production (Erman, 2005). Problems with local people's claims to mining lands in Ombilin had caused stagnation in production. Horizontal and vertical conflicts emerged and even threatened the city because the miners wanted to burn it down. Coal fields were controlled by community miners, each protected by thugs, even thugs from outside West Sumatra.

Second, coal production as a source of government revenue (PAD) cannot be expected, because coal deposits with existing mining technology are no longer efficient, except when applying deep mining technology at high costs. In that situation, the idea emerged to look for new ways to develop the city. The city government held various meetings, with various actors, such as academics, bureaucrats, politicians, corporate, and community leaders at the end of 1999 and early 2000. Finally, the government established a new city Vision and Mission "Sawahlunto, City of Civilized Mining Tourism" in 2002. The vision and mission has been designed until 2020. The vision and mission were based on the fact that coal exploitation in the surrounding of Sawahlunto has left many legacies, in the form of many complete building sites created by the Dutch with their rich history and culture. The vision and mission of this city cannot be separated from government policies at the national and global levels that rely on sources of income from the tourism sector.

Third, sectoral innovation (in tourism sector) carried out in realizing the city's vision and mission is to revitalize several mining sites that function for various purposes. i. converting the Ransoem warehouse to become a Gudang Ransoem museum, maintaining the weaving museum and an office for the Tourism Office; ii. rehabilitating several buildings such as the Ons Belang Cooperative shop, old houses around the market, the Chinese Captain's house, the societeit building, the Ombilin hotel, and the company doctor's office; iii. reopening the former deep mine and using it as a tourist attraction, famous for its "Mbah Suro" mine hole, iv. enabling the building at the train station to become a train museum. Until 2018, the city of Sawahlunto already has 6 museums. These museums were built using the old houses of mining company officials. v. turning the "Dutch Sizing Plan" building into an office and the surrounding area as a children's play area and a pop up market every Sunday. vi. The former mining sites are now used for orchards, zoos, water tourism, horse races, and motor crossings.

Fourth, local community participation. To prepare accommodation for tourists, the city government encouraged homeowners in Sawahlunto to make their houses as homestay. Homestays were originally located around the old town in Sawahlunto, now it is starting to spread towards the outskirts of the city, such as Talawi and Muara Kalaban areas. To create service and comfort for clients, the government provides various management training for homestay owners. There are around 41 active homestays and the majority are Traveloka members. In fact, homestay owners actually provide better service to their clients, because it is evident that visitors were more convenient and secure staying at a homestay than at a hotel. (Interview with homestay owners, September 2019). One of the homestays that got the best predicate in Southeast Asia in 2019 was the Oma homestay located in the village of Air Dingin village. This homestay now has its own association. 
Fifth, historical and cultural-based innovation. City government revitalizes historical and cultural-based innovations that are embedded in society; i. revitalizing the tradition of eating together in every year of city anniversary. The tradition of eating together involves all people who brought a variety of traditional foods in each village to be enjoyed together at the meeting centre in Kota Lama; ii. encouraging the activities of various arts groups from Minang, Java, Sunda, Batak, and China. Various cultural creativities, such as new dances inspired by ethnic Chinese, weaving, and coal mining were created. This reflects ethnic and cultural plurality in the city of Sawahlunto, iii. marketing the innovation products. Some of these new innovations are not only in the local or provincial level, but also for the international scope. For example, the International Festival of Traditional Music has involved many traditional musicians from various countries since 2013. The Sawahlunto International Songket Carnival (SISCa) has been held since 2015 and is still ongoing until 2019; iv. weaving training for the younger generation outside the village of origin of weaving, Silungkang. Training includes the procurement of raw materials, colouring, and using of songket for various purposes (Interview with the Mayor of Sawahlunto, 2018).

\subsection{Transformation from a civilized mining tourism city to a World Heritage City}

The mining town that has transformed the face of a ghost town into a beautiful, innovative, and productive city has two characteristics that led to it becoming a world heritage city, namely interplay of mining technology between Europe and its colony global industrialization and the existence of zone for World Heritage.

First, the interplay of mining technology between Europe and its colony for global industrialization in the second half of the $19^{\text {th }}$ century occurred: $i$. The Ombilin coal mines of Sawahlunto exhibit a significant interchange of the mining technology between Europe and its colonies. This complex technological ensemble was planned and built as a fully-integrated system designed to enable efficient deep-bore extraction, processing, transport, and shipment of industrialquality coal. This was shaped by local knowledge concerning geological formations in the tropical environment and by the local traditional practices (is based on Criteria. ii) The Ombilin coal mines of Sawahlunto is an outstanding example of a technological ensemble designed for maximum efficiency in the extraction of key, strategic natural resources, seen from grade coal. It illustrated characteristics of the later stage of global industrialization in the second half of the 19th century and early 20 th century when engineering technologies and complex systems of production gave rise to the globalized economy of industry and commerce (Criterion IV, UNESCO).

Second, the existence of Zone for World Heritage. Three areas as an integrated system of coal exploitation and transportation, covering there zones recognized by UNESCO as World Heritage. Area A, consists of open pit mines and labyrinthine underground mining tunnels together with on-site coal processing facilities, supported by a full-facility purpose-built mining town nearby at Sawahlunto. Area B is an ingeniously engineered rack mountain railway together with numerous rail bridges and tunnels, linking the mines to the coastal seaport, across 155 kilometers of rugged mountain terrain. Area $\mathrm{C}$ is a dredged harbor and newly-constructed seaport at Emma Haven on Sumatra's Indian Ocean coast from where the coal was shipped throughout the Netherlands East Indies (ICOMOS, UNESCO). These three zones have collected 7 regencies and cities in West Sumatra which are traversed by the railroad to the seaport.

The efforts to gain UNESCO recognition had been starting since the leadership of Mayor Amran Nur (2003-2013). Through his visionary leadership, the network of cooperation had expanded. First, in collaboration with a World Heritage City, Malacca, it became a twin city. They learned from Malacca regarding how to proceed with proposals and look for Universal Outstanding Value for Sawahlunto, as well as exchanging the collected information. Second, they built a network with experts and institutions, both at the national level and the regency cultural office, which includes experts and archaeologists who are members of ICOMOS, and international consultants who 
have a lot of experience in submitting proposals to UNESCO. All of the meetings were held in Sawahlunto, Padang and Jakarta, and long debates took place in determining objects, sites and regions, because the railroad network covers 7 urban regencies before arriving at Teluk Bayur Harbor (Emma Haven).

The struggle to get recognition did not go smoothly, even though the data collection regarding the heritage sites that were to be submitted was complete. The first step was to submit a proposal to the Ministry of Culture successfully, even beating the proposal from DKI Jakarta. The central government dispatched a team of researchers to check the extent to which this proposal could be proven in Sawahlunto. In the next step, the Ministry of Culture began to intervene by bringing the experts who administered reports to UNESCO. On March 17, 2017, the legacy of the Ombilin Coal Mine, Sawahlunto, was finally included as a tentative list in UNESCO. From UNESCO, there were experts to check all heritage sites. Finally, on July 6, 2019, at the UNESCO meeting in Azerbaijan, Sawahlunto was designated as a World Heritage City. This determination has an impact on a heavier responsibility to manage the city for the future in a sustainable manner.

\section{DISCUSSION}

From the explanation of changing stages in system innovation above, it can be seen how the discovery and exploitation of coal resources have brought interrelated changes in various fields, not only changing the physical Sawahlunto but also bringing multi-dimensional changes, namely: transformation of the government sector, economic development trajectory, social-political transformation of society.

\subsection{Multi-dimensional change}

\subsubsection{Transformation in the field of government}

Transformation has also taken place in the government sector. The coal discovery has brought important changes for Sawahlunto, which was originally a village to become the center of government. Sawahlunto was included in the alignment of Koto VII with the center of government in Silungkang, then changed to the residence of Sawahlunto in 1903 (Staatsblad, 1905). In 1911 it was made the City led by a Burgerlijken stand ("Mayor"). With this rapid development, in 1914 Sawahlunto was made the capital of Afdeeling Tanah Datar and moved from Batusangkar because the workload of the government was getting heavier, both as the capital of Sawahlunto residence. Onderafdeeling Sawahlunto and Afdeeling Tanah Datar and as a mining town, the status of Sawahlunto was finally established as Gemeente (Kotapraja) in 1918. In running the government, the mayor is assisted by a City Council (Gemeente Raad) consisting of 5 representatives from Europe, 3 Indigenous and 1 Chinese. The "Mayor" was immediately held by the Head of Afdeeling Tanah Datar. Since then, the city has experienced regional expansion. In 1929, the area of Sawahlunto City was expanded to become 577.7 ha (Staatsblad no.400 in 1929). The area of the city of Sawahlunto did not change until it was expanded again to $27,347.7$ ha in 1990 (Asoka et al., 2005).

\subsubsection{The trajectory of economic development}

For the economic sector, coal exploitation and the growth of urban communities and mining communities had brought transformation to the economic sector, market development, and cooperative shops, and have had a double impact on the urban economy. Because of that, the market grew to serve the needs of the mining community. Chinese traders and Minangkabau traders from the area around Sawahlunto, especially from Silungkang came to trade in the Sawahlunto market. However, the city's economic development trajectory runs parallel to the development of the coal economy. Therefore, after the company was paralyzed, production was stagnant due to attacks from local residents after the 1997/1998 Regional Economic Crisis and political transformation from the New Order regime to the Reform Era. Local people protested and claimed that their lands were used by the mining company. Therefore, the government could no longer expect economic contributions from companies, either from taxes and other redistribution. The sparkling city has turned into a quiet city with electricity services 
that were no longer guaranteed. Finally, the city entered the second stage of transformation, turning the mining city into a civilized mining tourism city.

\subsubsection{Socio-political transformation of society}

Mining town communities underwent socio-political transformations from time to time. In facing the livelihood situation at the mining area, they carried out various activities. First, in the social sphere, there were a variety of entertainment for various social classes of urban dwellers, ranging from European, Chinese, and natives to various ethnic groups. Solidarity was formed among the lower classes, and miners, initially 'shipmates, arisan, and sports associations. In the 1920s, they entered into a formal organization, the Union of Mining Workers' Associations. Second, in the political field, they carried out a rebellion known as the Silungkang rebellion in 1926/1927, (Zed, 1981; Kahin, 1996). The participation of mining communities and urban communities in various political organizations occurred until 1965. After 1965, some residents, miners, and their families were involved in this prohibited organization. Many were imprisoned and some left the city of Sawahlunto. During the New Order, the city community was reviving itself with developments in various fields, including the government policy to rebuild coal mine that had been neglected in the Old Order regime.

\subsection{Outcome of transformation, success key, and future challenge}

\subsubsection{Outcome of transformation}

The outcome of various revitalizations and innovations of the city government are ultimately for the welfare of local residents. This was shown by this economic growth which in turn has reduced the poverty rate from $17.5 \%$ in 2003 to $2.4 \%$ in 2010 (Interview with the Mayor, 2008, 2009, 2010).

There are several economic benefits from the system innovation in Sawahlunto, namely i. The civilized mining town has drastically increased tourist visits, from 32,000 in 2003 to 650,000 in 2010 . These tourist visits have had a positive impact on city residents, such as homestay owners, the informal sector (food vendors), and songket weavers. City dwellers also enjoy sightseeing in their own city; ii. Offering the visitors for historical and cultural tours of the mine by building modern tours for children and adults. For example, the Waterboom, tourism for children built by the city government, has experienced tremendous progress, drawing tourists from various other cities, even from Jambi province; iii. The creation of new economic fields is also a priority for the city government. In the agricultural sector, the government provides cacao seeds, lemon grass, patchouli cuttings, and a program to increase rice production by planting one stick of rice and providing free fertilizer. In the livestock sector, the government encourages people to raise cows, and most illegal miners were provided with capital for opening small plantation or to do micro business; iv. The emergence of new economic activities as the positive impact of the development of tourism development objects. This has been shown by the development of informal sector, selling a variety of foods and weaving shops both in the city center and especially along the road of Muara Kalaban district.

\subsubsection{Success key}

First, the leadership factor. The key to the success of bringing Sawahlunto from a ghost town to a cultured mining tourism city cannot be separated from the leadership, experience, and network possessed by Amran Nur, the mayor who was elected for two terms (2003-2010). The ITB graduate engineer was known as a successful entrepreneur in Jakarta and has a network of ITB alumni who held many important positions in the government bureaucracy. His passion for building his city shown by revitalizing its mining heritage, history, and culture, integrating modern tourism and at the same time improving the economy of the urban population by encouraging the agricultural and livestock sector ("How Amran Nur Juggled the Ghost Town of Sawahlunto" Tempo. co, 11 December 2012 ). Amran Nur's success was inherent in his ability to collaborate with various officials at the bureaucratic level, down to the level of the Vice President, scientists, the 
public, and business actors. In fact, in establishing cooperation among the Indonesian Heritage Cities (Kota-Kota Pusaka Indonesia), Amran Nur was elected as Chairman, a position that made it easier for him to absorb the experiences of other heritage cities in Indonesia for the advancement of the city of Sawahlunto.

Second, the heritage asset factor. Amran Nur's success in integrating various interests of actors to revitalize heritage assets had opened a key path to success in transforming the mining tourism city and towards World Heritage recognized by UNESCO. Innovation systems do not fall from the sky, but because there are accumulations of previous niches (asset functions) (Geels, 2004). In achieving recognition as a World Heritage City, the city government entered a series of negotiations with the company. Since the heritage sites belong to the PTBA-UPO company, a condition was not easy, because the power of the company is much stronger than that of the government for more than a century. This power has now been "returned" to the city government since the era of regional autonomy. Therefore, in this transformation process, there was some kind of resistance (hidden resistance) on the part of the company. The discussion between the two parties finally reached an agreement to strive towards recognition as a World Heritage City. Apart from companies, the city government had a wide and variety of cooperation with state actors at the regional and central levels from various ministries, including the Cultural Heritage Center, Batusangkar, scientists (architects, historians, environmentalists, cultural observers, photographers, journalists), entrepreneurs, Ministry of Tourism, Ministry of Public Works, and Ministry of Industry and Trade.

Third, the success of the application of 'reproduction' type of multi-level perspective (MLP) which refers to incremental change along existing trajectories (Geels \& Kemp, 2007). Actually, this case started an from isolated, small village to a mining town that equipped with expansion of mining activities and the development of infrastructures, and public facilities for mine workers, common people, and local government. The changes were not separated from actors from outside of the village, such as W.H. de Greeve, a young mining engineer from the Netherlands who discovered a rich coal. Then, it was followed by a decision from the colonial government to manage coal mines and to construct the town. The next trajectory was the development of colonial stateowned company, Het Ombilin Steenkolenmijnen. They were supported by the colonial government who demanded coal as energy resources. The following stage was when the coal mines deposits were exhausted and economically inefficient to mine anymore. The developed mining town changes to a ghost town when the mine workers laid off and most people went out of the city. Therefore, the next stage emerged. Local government tried to solve the problems by putting the ghost town as civilized mining tourism city. The consistency of local government in managing the program of civilized mining tourism city has facilitated the change from a ghost town to civilized mining tourism city, and finally to a World Heritage of Sawahlunto. In order to run this program smoothly, various actors collaborated to bring the city to World Heritage.

The above transitions come through dynamic processes within and between three analytical levels: i) niches, protected spaces and the locus of world heritage for radical innovations in tourism, which was initiated by the main actor, the Major of Sawahlunto city; ii) socio-technical regimes, which represented the institutional structure of existing systems in civilized mining tourism city, leading to pathways towards incremental change from ghost town to World Heritage City; and iii) exogenous socio-technical landscape developments, which was supported by various actors' collaborations to bring the city to World Heritage. Such processes have been widely discussed in literatures (Geels \& Schot, 2007; Geels, 2019a; Geels, 2019b; Kohler, et al., 2019; Turnheim, et al., 2020).

\subsubsection{Future challenge}

The recognition as a World Heritage city is a new episode for the city government to manage the city going forward. This UNESCO recognition has demanded future city management according to the requirements issued by UNESCO. Recognition as a world heritage city is a new 
transformation that must be done in terms of preserving the historical and cultural heritage of mining, and preserving the landscape for education and the welfare of its people. To succeed this goal, various new innovations are needed to create the city of Sawahlunto which is preserved with various historical and cultural sites and advanced people and environment. This is a long process of transformation, from a defunct mining city, to a mining company, PTBA-UPO, which has stopped producing since 1999, to a World Heritage Mining City. The transformation process from a ghost mining town to a civilized mining tourism city which was recognized by UNESCO as a World Heritage, provides challenges for all stakeholders to fulfill further requirements set by UNESCO as a commitment of receiving World Heritage awards. Finally, in dealing with COVID-19, the Ombilin administration has a challenge to design and implement the digital ecosystem of tourism for the future of local people welfare.

\section{CONCLUSION}

The stages of transforming a historical and cultural area into a world heritage for tourism space that had been pursued by the Ombilin coal mines of Sawahlunto involved multi-dimensional process. The discovery and exploitation of coal resources have brought interrelated changes in various fields, not only changing Sawahlunto physically but also bringing multi-dimensional changes, namely transformation of the government sector, economic development trajectory, and social-political transformation of society.

The economic benefit of transformation for local people are increase in city resident income from increased tourist visits, the informal sector (food vendors), songket weavers, the creation of new economic fields in the agricultural sector and live livestock sector, and the emergence of new economic activities.

The success key factors for Ombilin as a World Heritage City are: first, the key to the success of bringing Sawahlunto from a ghost town to a cultured mining tourism city cannot be separated from the leadership. Second, the heritage asset factor that articulated by leadership success in integrating various interests of actors to revitalize heritage assets. It had opened a key path to success in transforming the mining tourism city and towards a World Heritage recognized by UNESCO. Finally, recognition from UNESCO as a World Heritage provides challenges for all stakeholders, which are: i. to fulfill the further requirements set by UNESCO as a commitment of receiving World Heritage awards, and; to design and implement the digital ecosystem of tourism for the future of local people welfare.

\section{REFERENCES}

Amir, S., Osman, M.M., Bachok, S., \& Ibrahim, M. (2015). Sustaining local community economy through tourism: Melaka UNESCO world heritage city. Procedia Environmental Sciences, 28, 443-452.

Asoka, A., Samry, W., Zubir, Z., \& Zulqayyim. (2005). Sawahlunto, dulu, kini, dan esok: menyongsong kota wisata. Padang: Pusat Studi Humaniora, Universitas Andalas.

Ateş, Y. (2016). The significance of historical mining sites as cultural/heritage resources: A case study of Zilan Historical Mining Site, Erçiş, Van, Turkey. Journal of Underground Resources, $5(9), 15-24$.

Bichler, B. F. (2019). Designing tourism governance: The role of local residents. Journal of Destination Marketing \& Management, https://doi. org/10.1016/j.jdmm.2019.100389

Badan Pusat Statistik Kota Sawahlunto, 2010.

Burns, D. (2007). Systemic action research, a strategy for whole system change. Bristol: The policy press.

de Brujin, H., van der Voort, H., Dicke, W., de Jong, M., \& Veeneman, W. (2004). Creating System Innovation: How Large Scale Transitions Emerge. Leiden/London/New York: A.A. Balkema Publisher.

Cosma, S., Paun, D., Bota, M., \& Fleseriu, C. (2014). Innovation - a useful tool in the rural tourism in Romania. Procedia - Social and Behavioral Sciences, 148, 507-515.

Colombijn, F. (1992). Uiteenlopende Spportrails, de vershillende Ideen over Spporweg aanleg en ontginning van het Umbilin-kolenvelds in West Sumatra 1868-1891. Bijragen en Mededelingen Betwreffende de Geschiedenis der Nederlanden 107, 437-58. 
Dans, E. P. \& González, P. A. (2020). Sustainable tourism and social value at World Heritage Sites: Towards a conservation plan for Altamira, Spain. Annals of Tourism Research, Volume 74, 68-80.

Dwangarbeiders. (1925). Dwangarbeiders of contract koelies als werkvolk in de Ombilinmijnen, Indische Gids, 47(1), 559-562.

Erman, E. (2005). Membaranya Batubara: Konflik Kelas dan Etnik, Ombilin-Sawahlunto, Sumatera Barat (1892-1996). Depok: Desantara.

Erman, E. (2005). Illegal Coalmining in West Sumatra: Access and Actors in the Post Soeharto Era, in Reksosudarmo, B. (ed.). (2005). The Politics of Indonesia's Natural Resources. Singapore: Institute of Southeast Asian Studies.

Erman, E. (2007). Deregulation of the tin trade and creation of a local Shadow State". In Henk Schulte Nordholt and Gerry van Klinken. Renegotiating boundaries: Local politics in Post-Suharto Indonesia. Leiden: KITLV Press.

Farid, S.M. (2015). Tourism management in World heritage sites and its impact on economic development in Mali and Ethioppia. ProcediaSocial and behavioral science, 211, 595-604.

Geels, F.W. (2004). Understanding system innovations: A critical literature review and a conceptual synthesis. In Elzen, B., Geels, F.W., \& Green, K. System innovation and the transition to sustainability, theory, evidence, and policy. Cheltenham: Edward Elgar Publishing.

Geels, F.W. \& Schot, J. (2007). Typology of sociotechnical transition pathways. Research Policy, 36(3), 399-417.

Geels, F.W. \& Kemp, R. (2007). Dynamics in socio-technical systems: Typology of change processes and contrasting case studies. Technology in Society, 29(4), 441-455.

Geels, F.W. (2019a). Micro-foundations of the multi-level perspective on socio-technical transitions: Developing a multi-dimensional model of agency through crossovers between social constructivism, evolutionary economics and neo-institutional theory. Technological Forecasting and Social Change, 152, 119894.

Geels, F.W. (2019b). Socio-technical transitions to sustainability: A review of criticisms and elaborations of the Multi-Level Perspective. Current Opinion in Environmental Sustainability, 39, 187-201.

de Greeve, W.H. (1871). Het Ombilienkolenveld in de Padangsche Bovenlanden en het Transportstelsel op Sumatra's Westkust.
Ismagilova, G., Safiullin, L., \& Gafurov, I. (2014). Using historical heritage as a factor in tourism development. Procedia - Social and Behavioral Sciences 188, 157-162.

Jelen, J. (2018). Mining Heritage and Mining Tourism. Czech Journal of Tourism, 7(1), 93-105. DOI: 10.1515/cjot-2018-0005.

Jokilehto, J. (2006). Considerations on authenticity and integrity in world heritage context. City \& Time, 2(1), 1.

Kahin, A.R. (1996). The 1927 communist uprising in Sumatra; A Reappraisal. Indonesia, 62, 19-35.

Khlaikaew, K. (2015). The cultural tourism management under context of world heritage sites: Stakeholders' opinions between Luang Prabang Communities, Laos and Muang-kao Communities, Sukhothai, Thailand. Procedia Economics and Finance, 23, 1286-1295.

Köhlera, J., Geels, F.W., Kern, F., Markard, J., Onsongo, E., Wieczorek, A., Alkemade, F., Avelino, F., Bergek, A., Boons, F., Fünfschilling, L., Hess. D., Holtz, G., Hyysalo, S., Jenkins, K., Kivimaa, P., Martiskainen, M., McMeekin, A., Mühlemeier, M.S., Nykvist, B., Pel, B., Raven, R., Rohracher, H., Sandén, B., Schot,J., Sovacool, B., Turnheim B., Welch, D., \& Well, P. (2019) An agenda for sustainability transitions research: State of the art and future directions. Environmental Innovation and Societal Transitions, 31, 1-32.

Martinez-Perez, A., Elche, D., \& Garcia-Villaverde, P.M. (2018). From diversity of interorganizational relationships to radical innovation in tourism destination: The role of knowledge exploration. Journal of Destination Marketing \& Management, 11, 80-88.

Milne, L. (2011). Significance of aesthetic and heritage values in a public policy environment: Victoria Theatre case study. (Master thesis), Auckland University of Technology.

Milwood, P.A., \& Maxwell, A. (2020). A boundary objects view of Entrepreneurial Ecosystems in tourism. Journal of Hospitality and Tourism Management, 44, 243-252.

Petric, L., Hell, M., \& van Der Borg, J. (2020). Process orientation of the world heritage city management system. Journal of Cultural Heritage, 46, 259-267.

Sigala, M. (2020). Tourism and COVID-19: Impacts and implications for advancing and resetting industry and research. Journal of Business Research, 117, 312-321. 
Staatsblad van het Nederlandsch Indie, 1905.no.396. Staatsblad van het Nederlandsch Indie, 1929, no.400.

Turnheim, B., Asquith, M., \& Geels, F.W. (2020). Making sustainability transitions research policy-relevant: Challenges at the sciencepolicy interface. Environmental Innovation and Societal Transitions, 34, 116-120.
Wang. L., \& Xiao, S. (2020). Tourism space reconstruction of a world heritage site based on actor network theory: A case study of the Shibing Karst of the South China Karst World Heritage Site. International Journal of Geoheritage and Parks, 8 (2020) 140-151.

Zed, M. (1981). Pemberontakan Komunis Silungkang; Sebuah Gerakan Sosial. (Doctoral Thesis). Gadjah Mada University. 